\title{
Accreditation of research in the thermo-climatic chamber - various aspects
}

\author{
Artur Gawlik ${ }^{1}$, Piotr Kucybała ${ }^{1}$, Danuta Owczarek ${ }^{1}$, and Janusz Pobędza ${ }^{1, *}$ \\ ${ }^{1}$ Cracow University of Technology, Mechanical Department, Al. Jana Pawła II 37, 31-864 Kraków, \\ Poland
}

\begin{abstract}
One of the important aspects in the implementation of new products for production in the open field is the assessment of the impact of environmental conditions on their operation. Typically thermo-climatic research is carried out for such project. The laboratory of Techno-climatic Research and Heavy Duty Machines of Cracow University of Technology, equipped with a large-sized thermo-climatic chamber conducts this type of research. Bearing in mind the assurance of high quality of the conducted research, the quality management system (QMS) was developed and implemented. The article describes the requirements, scope and process of obtaining a Polish Centre for Accreditation (PCA) certificate.
\end{abstract}

\section{Introduction}

\subsection{Motivation for conducting techno-climatic research}

The constantly increasing range of requirements as to the quality and reliability of manufactured machines and devices force not only the implementation of production quality management systems, but also the development of standards and requirements that the machines and devices must fulfill. It is also necessary to develop experimental test methods and procedures that allow checking and verifying whether the requirements are met. Such procedures are developed, amongst others, in accredited laboratories and institutions that rely on many years of research and design experience, and guarantee a very high quality of conducted research.

Currently, in the phase of machines and devices designing process, advanced IT tools are used as well as the constructors' shared experiences and knowledge exploited. This makes it possible, to a large extent, to meet the functional requirements, strength, durability and reliability conditions. However, despite the use of more and more perfect systems for computer modeling and simulation, there is still a need to conduct experimental research that will verify the effects of design works [1].

Vehicles, mobile machines and engineering devices intended for open field operation, must be adapted to various and changeable climatic conditions, and thus it is necessary to conduct research determining the impact of various climatic exposures on the functionality,

\footnotetext{
* Corresponding author: janusz.pobedza@mech.pk.edu.pl
} 
reliability and durability of the constructed and manufactured equipment. In addition, ensuring the comfort of machine operators, vehicle drivers and passengers is also an important issue.

\subsection{Experience in techno-climatic studies}

Research on the impact of environmental exposures on machines and engineering objects has been carried out at the Cracow University of Technology since 1973. For this purpose, a large-sized thermo-climatic chamber has been used, with dimensions: $20 \mathrm{~m} \times 6 \mathrm{~m} \times 6 \mathrm{~m}$ and with temperature range down to $-40^{\circ} \mathrm{C}$. Various objects have been subjected to research: vehicles, earth moving machines, military vehicles, construction and road machines, postal and vending machines, and even a helicopter and a railway wagon [1-5].

As part of the research, particular attention was paid to the operation of diesel engine start-up systems. Much attention was also devoted to determining the characteristics of hydraulic drive and control systems and assessing their reliability under conditions of low temperature $[6,7]$. The evaluation of the heating and air-conditioning systems performance was also an important area of research [8].

Currently, techno-climatic research is carried out in a new facility, characterized by high cooling capacity and the largest, in this part of Europe, dimensions of the test space. The examples of objects tested in a thermo-climatic chamber are presented in Fig. 1.
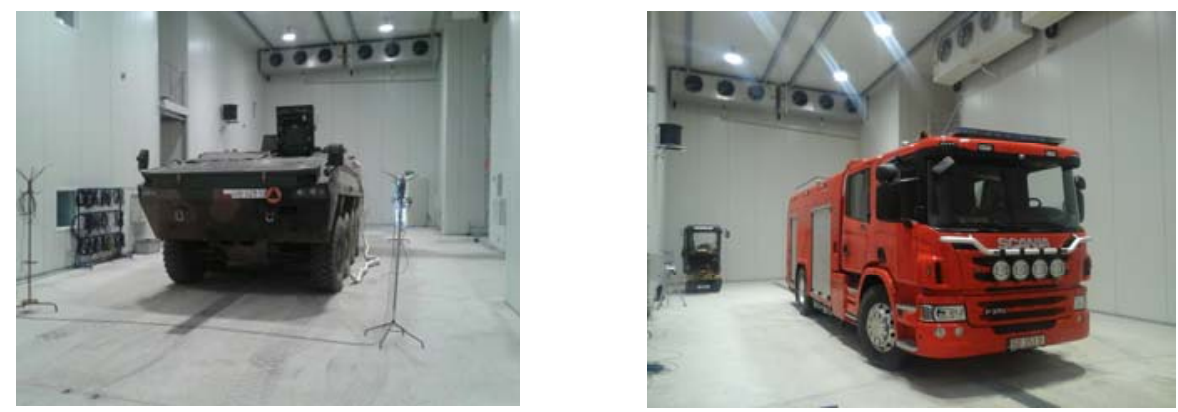

Fig. 1. The examples of objects tested in a thermo-climatic chamber: military vehicle, fire truck.

The main area of the thermo-climatic chamber is the test space with the following dimensions: length $19.4 \mathrm{~m}$, width $7.7 \mathrm{~m}$ and height $8 \mathrm{~m}$. An additional space, which can be used during tests, is the , $3.7 \mathrm{~m}$ long entry gate (Fig. 2). Large dimensions of the test space ensure sufficient distance of the tested object from the walls of the chamber, and thus allow to minimize the impact of possible heat sources on measuring transducers.

The equipment of the thermo-climatic chamber consists of a refrigerating and heating systems, supervised and monitored by an integrated control unit, whereas the main temperature registration system is composed of thirty Pt100 temperature sensors (class A) connected in a three-wire system. The location of the sensors is determined each time, individually for the tested object, in accordance with the requirements of the relevant standard and/or as agreed with the client.

To increase the veracity of the obtained tests results, the research quality assurance system has been elaborated and introduced in the Laboratory of Techno-climatic Research and Heavy Duty Machines, which is confirmed by the certificate of Polish Centre for Accreditation (PCA). 


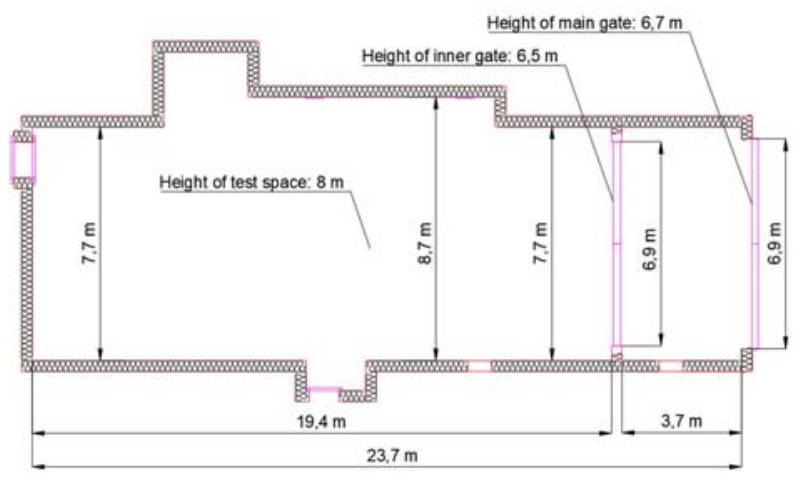

Fig. 2. The view of the thermo-climatic chamber testing space.

\section{Accreditation procedure}

\subsection{PCA accreditation requirements}

Accreditation should be understood as a formal recognition by the authorized accreditation body of competences of organizations operating in the field of conformity assessment, that is, certification and inspection organizations or technical laboratories. The rules of accreditation are included in international standards and guidelines, in which, amongst others, are defined requirements for accredited organizations. Getting the accreditation means that accredited body has been positive assessed according to these standards and guidelines. In Poland in this field operates the Polish Centre for Accreditation (PCA) which is the national accreditation body authorized to accreditation of conformity assessments organizations [9].

At present, PCA conducts accreditation and supervises processes, included but not limited to testing, calibration and processes of medical laboratories. The Laboratory of Techno-climatic Research and Heavy Duty Machines is understood here as a testing laboratory. The PCA application rules are presented in DA-01 document [9] and more detailed requirements for testing laboratories are presented in DAB-07 [9] document. Both can be downloaded from PCA website. The laboratory can gain the accreditation after fulfilling all accreditation requirements specified in DAB-07 document while performing tests using methods applied for accreditation. The accreditation requirements for testing laboratories are briefly as follows:

- PN-EN ISO/IEC 17025: General requirements for the competence of testing and calibration laboratories [10],

- DA-05 policy for participation in proficiency testing [9],

- DA-06 policy for ensuring traceability [9],

- documents describing test or calculation methods used in a laboratory, normative documents or own laboratory procedures,

- additional documents used for laboratory accreditation.

In the process of gaining the accreditation the Laboratory of Techno-climatic Research and Heavy Duty Machines had to fulfil all accreditation requirements, which was done at the turn of the year 2017/2018 and finally it was granted accreditation on 12 April, 2018 AB 1678. 


\subsection{Preparation to accreditation - QMS of Laboratory of Techno-climatic Research and Heavy Duty Machines}

The accreditation applying process of Laboratory of Techno-climatic Research and Heavy Duty Machines started from completing and checking all necessary elements, such as competent staff, machines/equipment, finances, consent of the authorities and good quality management system (QMS) composed of various procedures which also included technical procedure.

The most time-consuming stage was the creation of QMS because the idea was to have the system which would be well-suited to the Laboratory specifics and which would be used for many different types of research. This system is composed of five sets of documents, as described below.

I. The Quality Manual - which, according to PN-EN ISO/IEC 17025 [10], includes or makes reference to the supporting procedures, also the technical ones. The goal of the quality manual is to outline the structure of documentation of the quality system. It is composed of seven chapters: (1) Presentation of the Laboratory of Techno-climatic Research and Heavy Duty Machines, (2) The Quality Policy Statement, (3) Supervision over the Quality Manual, (4) Management, (5) Technical requirements, (6) Annexes and (7) Related documents. One of the most important information of the Quality Manual is the Table 1, which presents the scope of research.

Table 1. Scope of research.

\begin{tabular}{|c|c|c|c|}
\hline $\begin{array}{l}\text { Subject of research / } \\
\text { product }\end{array}$ & $\begin{array}{l}\text { Type of activity / researched } \\
\text { features / method }\end{array}$ & $\begin{array}{c}\text { Related } \\
\text { documents }\end{array}$ & $\begin{array}{l}\text { No of } \\
\text { research } \\
\text { done }\end{array}$ \\
\hline $\begin{array}{l}\text { Cars and vehicles. } \\
\text { Mobile machines. } \\
\text { Objects and engineering } \\
\text { devices. } \\
\text { Objects with dimensions } \\
\text { up to: } \\
\text { L } 22 \mathrm{~m} \text { x W } 7.7 \mathrm{~m} \text { x H } 8 \mathrm{~m}\end{array}$ & $\begin{array}{l}\text { Resistance to temperature. } \\
\text { Temperature distribution in the } \\
\text { thermo-climatic chamber. } \\
\text { Temperature distribution in the } \\
\text { tested objects. } \\
\text { Scope: from }-50^{\circ} \mathrm{C} \text { to }+70^{\circ} \mathrm{C} \\
\text { Direct measurement method. }\end{array}$ & $\begin{array}{l}\text { PB01 issue } 4 \text { of } \\
19 / 02 / 2018\end{array}$ & $\mathrm{M}$ \\
\hline \multirow{2}{*}{$\begin{array}{l}\text { Special vehicles, including } \\
\text { military, police and rescue } \\
\text { applications. } \\
\text { Objects with dimensions } \\
\text { up to: } \\
\text { L } 22 \mathrm{~m} \times \mathrm{W} 7.7 \mathrm{~m} \times \mathrm{H} 8 \mathrm{~m}\end{array}$} & $\begin{array}{l}\text { Total resistance to elevated } \\
\text { ambient temperature. } \\
\text { Scope: to }+70^{\circ} \mathrm{C} \\
\text { Direct measurement method. }\end{array}$ & $\begin{array}{l}\text { NO-06- } \\
\text { A107:2005 p.4.2 } \\
\text { PB01 issue } 4 \text { of } \\
\text { 19/02/2018 }\end{array}$ & \multirow{2}{*}{$\mathrm{M}$} \\
\hline & $\begin{array}{l}\text { Total resistance to reduced ambient } \\
\text { temperature. } \\
\text { Scope: to }-50{ }^{\circ} \mathrm{C} \\
\text { Direct measurement method. }\end{array}$ & $\begin{array}{l}\text { NO-06- } \\
\text { A107:2005 p.4.3 } \\
\text { PB01 issue } 4 \text { of } \\
\text { 19/02/2018 }\end{array}$ & \\
\hline
\end{tabular}

II. The Quality Policy Statement - including, but not limited to: the Laboratory management's commitment to good professional practice and to the quality of testing in servicing of Laboratory customers, the management's statement of the Laboratory's standard of the service, the purpose of the management system related to quality and all other declarations required by PN-EN ISO/IEC 17025 [10].

III. Eight Quality Management System procedures:

P1 "Supervision of documents and records",

P2 "Overview of inquiries, offers and contracts, customer service, complaints",

P3 "Shopping",

P4 "Deviations, supervision of non-compliant tests, corrective and preventive actions", 
P5 "Internal audit and management review",

P6 "Staff",

P7 "Accommodation and environmental conditions, equipment, measurement consistency",

P8 "Ensuring the quality of results",

IV. One technical procedure - PB01 "Temperature resistance tests and temperature distribution tests in the thermo-climatic chamber and in the objects tested in it" together with one related instruction: I01/PB01 „Operation of refrigeration aggregates and heaters in a thermo-climatic chamber".

V. External documents - such as: norms for example NO-06-A107:2005 [11], PCA/EA documents, legal documents such as: Rector's orders, health and safety documents.

\subsection{Accreditation process}

The general accreditation process is described in DA-01 [9] document. It is always composed of documents review and on-site assessments. First, the organization has to submit an application, then the application is checked by the PCA staff and the assessment process is organized together with the appointment of the evaluation team. Next, the submitted documentation is checked by the team of auditors and an initial visit of auditors is optionally arranged. Then, an on-site assessment is carried out and after that auditors check the implementation of corrective actions. Finally, PCA makes a summary of the assessment results and the decision about accreditation and its scope is taken. If the decision is positive, the Laboratory is awarded the accreditation and is subjected to an annual supervision process. According to the act, the accreditation process cannot last longer than 12 months.

\section{Guidelines and conclusions}

The development of documentation as well as accreditation obtained by the Laboratory of Techno-climatic Research and Heavy Duty Machines contributed to the organization and improvement of the techno-climatic studies carried out at the Cracow University of Technology. The increasing range of requirements related to the resistance of machines and devices to extreme climatic conditions, prompts the Laboratory staff to develop and implement further accredited procedures: the ones related to the determination of the impact of humidity and/or light radiation. Another issue is to obtain the Accreditation in Defence and Security, which will confirm the competence of the Laboratory to perform activities related to the assessment of compliance of products for the needs of national defence and security in terms of features related to their resistance to different climatic conditions.

Regardless of researches focused on external commercial client, the chamber may be used to provide the extreme environments (temperature, humidity, light) in scientific investigations involving biotechnology processes $[12,13]$ or material properties [14-19] in real scale. The chamber has been already used to test human resistance to extreme conditions, what may be useful in construction models of human-company relationships [20-23]. Such experiments lead to huge datasets which typically require analysis [24, 25] deeper than typical statistical postprocessing. Certainly, the climatic chamber will be intensively used. 


\section{References}

1. W. Cichocki, S. Michałowski, J. Pobędza, Examination of working machines and engineering objects under environmental exposure conditions (Wyd. PK, Kraków, 2015)

2. W. Cichocki, A. Garbacik, K. Golec, K. Szewczyk, A new concept of numerical modeling of heating and start-up systems (Wyd. PK, Kraków, 1996)

3. J. Pobędza, A. Sobczyk, Adv. Mat. Res.-Switz., 849, 100 (2014)

4. A. Sobczyk, Improvement of Hydraulic System Efficiency by Means of Energy Recuperation (Wyd. PK, Kraków, 2011)

5. K. Szewczyk, E. Lisowski, J. Pobędza, Technical report of the R\&D project CPBP 02.05 (Kraków, 1990)

6. K. Szewczyk, J. Pobędza J., Proc. of $6^{\text {th }}$ Sci. Conf. on Control, Drive, Fatigue Strength and Designing of Construction Machines (Rynia, 1994).

7. K. Szewczyk, The influence of reduced temperature on the characteristics of hydraulic systems of heavy machinery (Wyd. PK, Kraków, 1991)

8. A. Gawlik, P. Kucybała, J. of KONES 24, 35 (2017)

9. Description of the accreditation system DA-01 $9^{\text {th }}$ Edition. (Polish Centre for Accreditation. http://www.pca.gov.pl, acc. date 2018-04-26)

10. Technical standard PN-EN ISO/IEC 17025.

11. Technical standard NO-06-A107:2005.

12. E. Skrzypczak-Pietraszek, J. Pietraszek, Acta Biol. Crac. Ser. Bot., 51, 62 (2009)

13. E. Skrzypczak-Pietraszek, I. Kwiecien, A. Goldyn, J. Pietraszek, Phytochem. Lett., 20, 443 (2017)

14. R. Ulewicz, J. Selejdak, S. Borkowski, M. Jagusiak-Kocik, Proc. 22rd International Conference on Metallurgy and Materials (Brno, Czech Republic, 1926, 2013)

15. R. Ulewicz, P. Szataniak, F. Novy, Proc. 23rd International Conference on Metallurgy and Materials (Brno, Czech Republic, 784, 2014)

16. P. Szataniak, F. Novy, R. Ulewicz, Proc. 23rd International Conference on Metallurgy and Materials (Brno, Czech Republic, 778, 2014)

17. E. Augustyn, M.S. Kozien, Acta Phys. Pol. 125, 164 (2014)

18. A. Dudek, A. Wronska, L. Adamczyk, J. Solid State Electrochem. 18, 2973 (2014)

19. E. Lisowski, G. Filo, Flow Meas. Instrum. 53, 269 (2017)

20. Kozien, E., Proc. 20 $0^{\text {th }}$ Int. Sci. Conf. on Economic and Social Dev. (ESD) (Prague, Czech Republic, 538, 2017)

21. A. Pacana, R. Ulewicz, Polish J. Environ. Studies 16, 165 (2017)

22. Kozien, E., Kozien, M.S., Proc. 26 ${ }^{\text {th }}$ Int. Sci. Conf. on Economic and Social Dev. Building Resilient Society (ESD) (Zagreb, Croatia, 210, 2017)

23. Kozien, E., Kozien, A., Proc. 26th Int. Sci. Conf. on Economic and Social Dev. Building Resilient Society (ESD) (Zagreb, Croatia, 326, 2017)

24. J. Pietraszek, A. Gądek-Moszczak, T. Torunski, Adv. Mat. Res.-Switz., 874, 139 (2014)

25. J. Pietraszek, A. Goroshko, Adv. Mat. Res.-Switz., 874, 145 (2014) 